Boundaries of Citizenship in Post-Wall Germany," Comparative Studies in Society and History 47, no. 2 [2005]: 235-51).

Along with Where the World Ended and the book series "New Anthropologies of Europe" from Indiana University Press that she coedited, these articles provide the rich intellectual legacy of an exceptional scholar and wonderful human being. A woman of tremendous generosity and kindness, Daphne Berdahl is dearly missed by her many friends and colleagues. In addition to her parents, she is survived by her husband, John Baldwin, and her daughters, Audrey and Eloise.

\author{
Matti BunzL \\ University of Illinois, Urbana-Champaign \\ November 2007
}

\title{
Lindsey Hughes, 1949-2007
}

Lindsey Hughes, professor of Russian history at the University of London's School of Slavonic and East European Studies, died on 26 April 2007. A leading historian of seventeenth- and eighteenth-century Russia for several decades, Hughes was one of the most important specialists on Peter the Great and his time. To many she was a friend as well as a colleague, and she will be missed as much abroad as in Britain.

Born on 4 May 1949 at Swanscombe in Kent, Hughes began to study Russian in secondary school and in 1967 went to Sussex University to continue in Russian. There she studied with Beryl Williams, Sergei Hackel, and Robin Milner-Gulland as well as spending a year in Moscow. She completed her graduate work at Darwin College, Cambridge, working on Moscow Baroque architecture with Nikolay Andreev. Finishing her doctorate in 1976, she began her teaching career at Queen's University Belfast at the height of the troubles in Northern Ireland. In many British universities Russian history was and is taught in the context of Russian studies, and when Hughes moved to Reading University in 1977, she taught literature, language, and history in the Russian department.

Just as Hughes was turning toward history from art history, the British government began to encourage smaller universities to close down Russian departments and centralize instruction in a few large centers. She was transferred in 1987 to the School of Slavonic Studies at London University in 1987, where she remained to the end of her life. By now committed to historical research, she published a brief biography of Prince V. V. Golitsyn in 1984, followed by Sophia, Regent of Russia (1990), the first and only scholarly study of Russia's first female ruler and her policies. Hughes never lost sight of the crucial importance of culture in the transformation of Russia during the late seventeenth century and the reign of Peter the Great. In her most important work, Russia in the Age of Peter the Great (1998), she devoted some 150 pages to cultural matters, as well as many chapters to family, personal networks, and other topics far from the traditional emphasis on institutional and social issues. Her second work on Peter, Peter the Great: a Biography (2002), provided the first biographical treatment of the reforming tsar since that of Reinhard Wittram nearly a half century ago. She managed to complete a study of the Romanov dynasty and had returned to her original interest in the art of the later seventeenth century and Peter's time.

Hughes was a major figure in British Slavic studies, one of the leaders of the Study Group on Eighteenth Century Russia, an important force at the School of Slavonic Studies, and editor of the Slavonic Review. An accomplished guitarist and singer, she had appeared on children's programs on Russian television as a student and in later life participated in local singing groups. She is survived by her husband, Jim Cutshall, who was with her for many years. Her former students as well as her colleagues throughout the world will miss her. 